\title{
Central Neurocytoma Presenting as Large Intraventricular Mass Diagnosed by Stereotactic Biopsy
}

\section{Nasuhi Engin Aydin* \\ Professor of Pathology, IzmirKatip Celebi University Faculty of Medicine, Turkey}

*Corresponding author: Nasuhi Engin Aydin, MD, Professor of Pathology, IzmirKatip Celebi University Faculty of Medicine, Ataturk Hastanesi, Patoloji Klinigi, Basın Sitesi, Yesilyurt, Izmir 35270, Turkey, Tel: +905466157058, E-mail: nasuhiengin@gmail.com

A 40-year-old man presenting with headache and dizziness of several months duration was found to have a large intraventricular mass during the clinical workup (Figure 1). A stereotactic biopsy of the mass revealed cellular neoplastic tissue with monotonous round cells (Figure 2). There was not any mitotic activity, necrosis, pleomorphism, microvascular proliferation (Figure 3).
Immunohistochemical staining revealed negative staining with leucocyte common antigen (LCA) (Figure 4) and glial fibrillarey acidic protein (GFAP) (Figure 5) in the neoplastic cells. However there was diffuse and strong synaptophysin positivity (Figure 6). These pathologic findings pointed to a central neurocytoma (CN) as outlined in the recent monograph of World Health Organization [1].

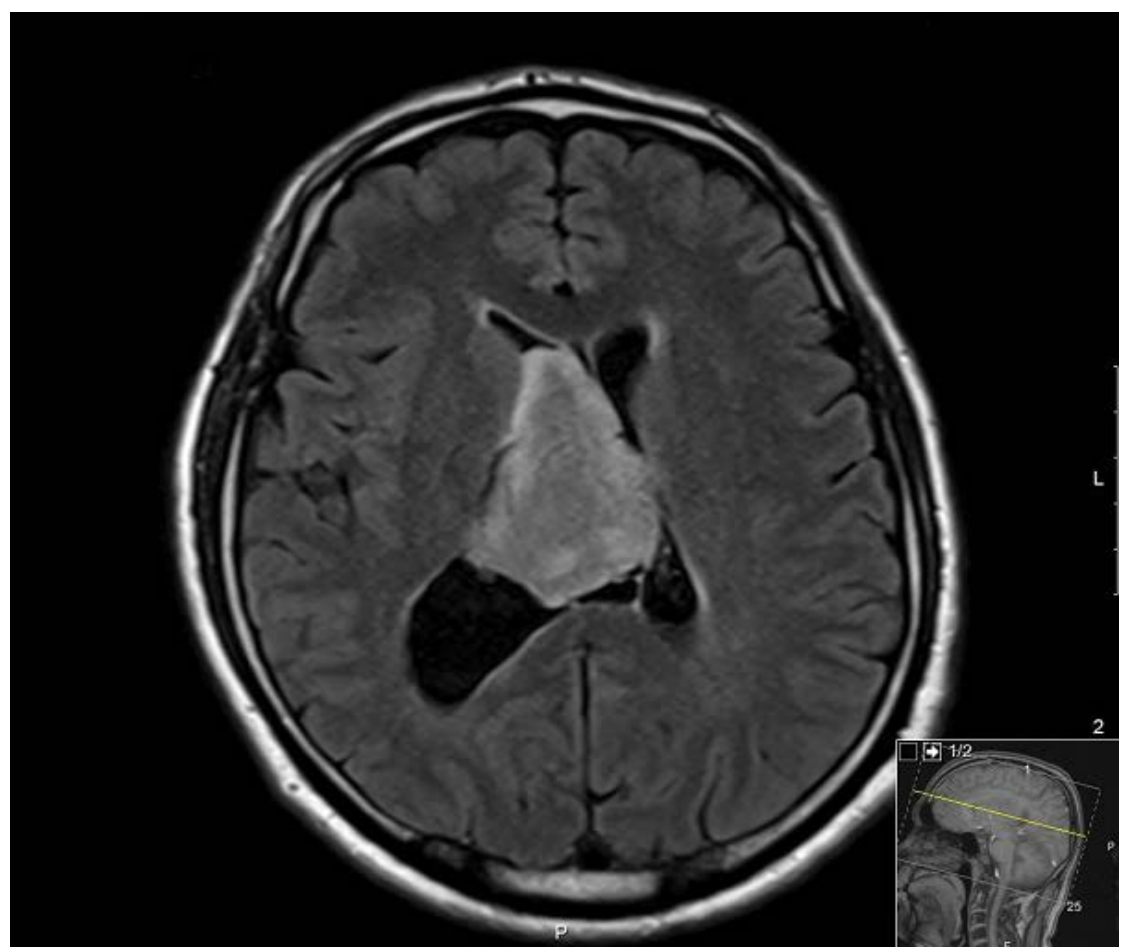

Figure 1: Magnetic Resonance Image (MRI): Axial non-contrast image showing a large relatively homogeneous intraventricular mass about $6 \mathrm{~cm}$ in greatest dimension.

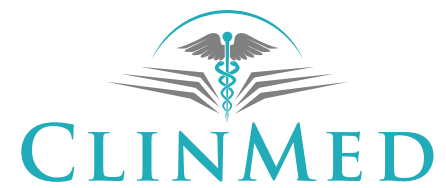

INTERNATIONAL LIBRARY
Citation: Aydin NE (2017) Central Neurocytoma Presenting as Large Intraventricular Mass Diagnosed by Stereotactic Biopsy. Clin Med Img Lib 3:059. doi.org/10.23937/2474-3682/1510059

Received: October 13, 2016; Accepted: April 17, 2017; Published: April 20, 2017

Copyright: (C) 2017 Aydin NE. This is an open-access article distributed under the terms of the Creative Commons Attribution License, which permits unrestricted use, distribution, and reproduction in any medium, provided the original author and source are credited. 


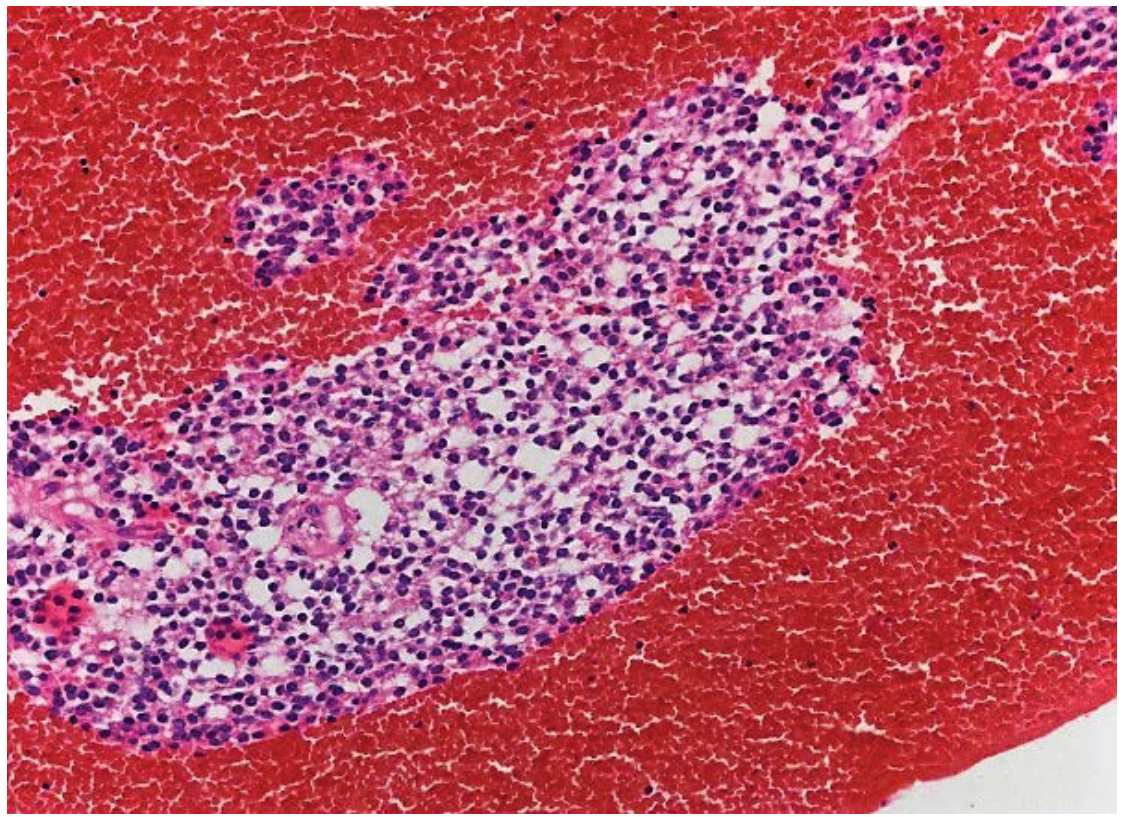

Figure 2: Low power view of the stereo tactic biopsy showing a cellular neoplastic tissue in a hemorrhagic background (hematoxylin and eosin x200).

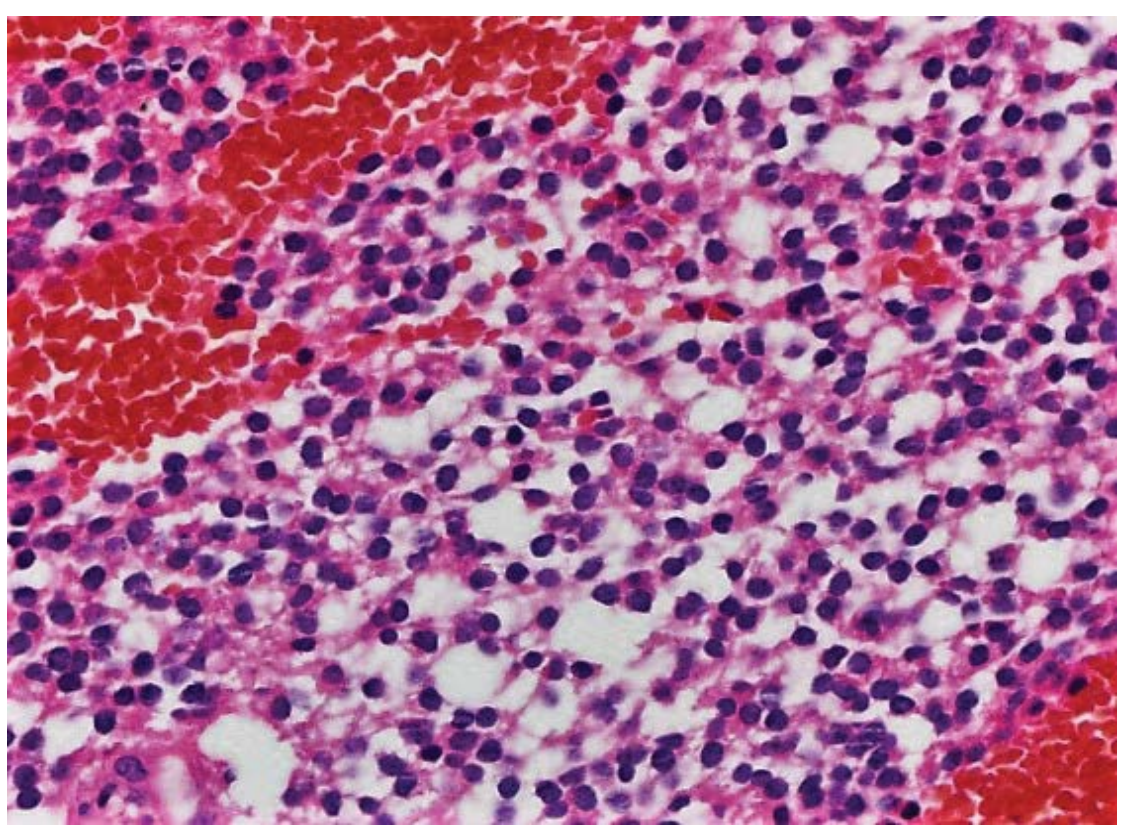

Figure 3: High power view showing monotonous round cells with clear cytoplasm without pleomorphism, vascular endothelial proliferation, mitotic activity and necrosis (hematoxylin and eosin $x 400$ ).

Central neurocytomas (CNs) are extremely rare tumors mainly seen in the 20-40 year age group with a pre dominant location in the lateral ventricles near Monro for amina, in the septum pellucidum or on the ventricle walls representing not more than $0.5 \%-0.7 \%$ of all intra cranial tumors [2,3]. Less than 500 cases of $\mathrm{CNs}$ have been described including large series $[2,3]$ since there cognition of $\mathrm{CNs}$ as a separate pathological entity in 1982 [4].

In a typical case of $\mathrm{CN}$ light microscopy shows honeycomb architecture with small, uniform, round cells with central nuclei with clear cytoplasm is dispersed with in a fibrillary stroma, mimicking a neuropil [1-4]. Chromatin has usually a salt and pepper appearance. Micro calcifications or microcysts can be present, but mitoses, microvascular proliferations and necrosis are not seen. Immunohistochemically, tumour cells show a strong and diffuse cytoplasm staining for the neuro endocrine marker synaptophysin, a calcium binding membrane protein of presynaptic vesicles. Staining with this marker is also observed in the stellate fibrillary zones. A few cells, which probably representing entrapped astrocytic glial cells, show staining for glial fibrillary acid protein (GFAP). A typical neurocytoma is a rare variant of $\mathrm{CN}$, with cellular pleomorphism, mi- 
totic activity, necrosis, or microvascular proliferation. $\mathrm{CNs}$ is believed to originate from progenitor bipotential (neuronal and astrocytic) cells which persist into adulthood in the periventricular region. In order to achieve a right diagnosis, a tumour biopsy is always necessary and to establish a risk of tumour recurrence or progression as well as to aid to classify the patients in high or low-risk groups [2]. Gross total tumour removal is the treatment of choice because of high rate of local control and survival [1-4].

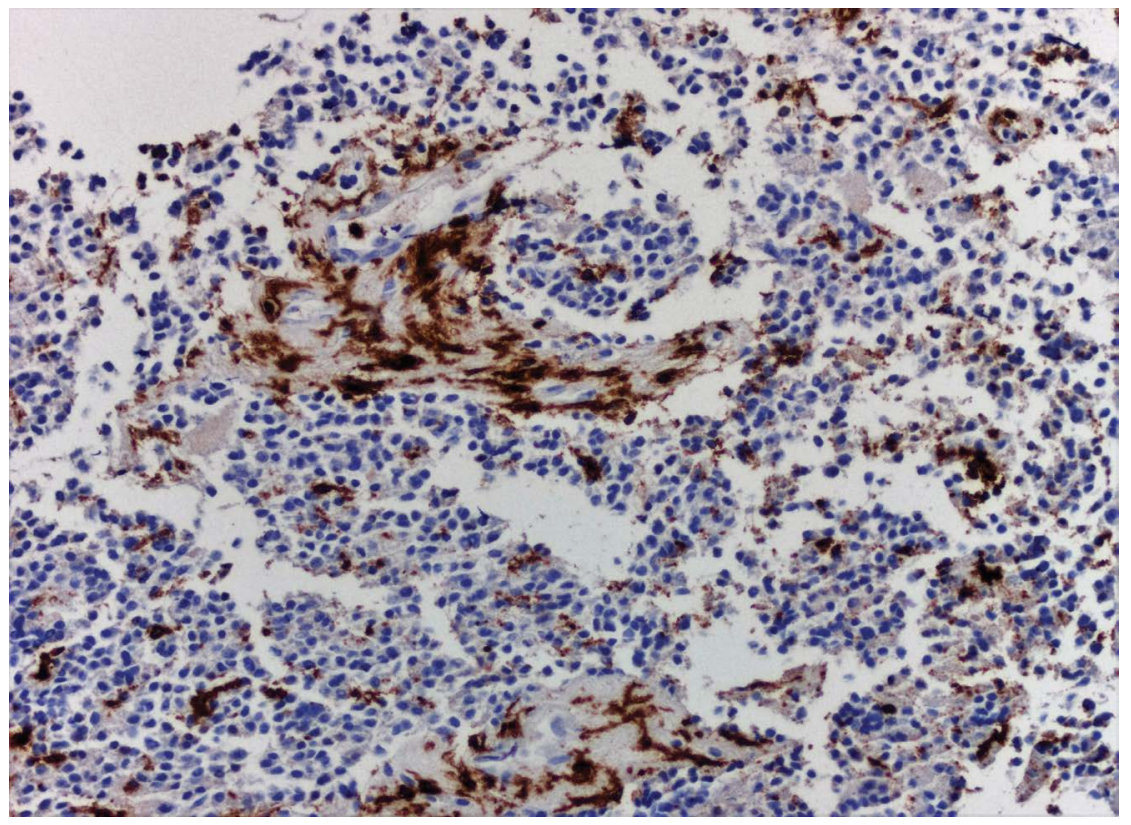

Figure 4: Focal positive reaction with LCA (CD45) antibody revealing a few lymphocytic cells with crushing artifact due to biopsy procedure among the neoplastic tissue (CD45 antibody, DAB chromogen x400).

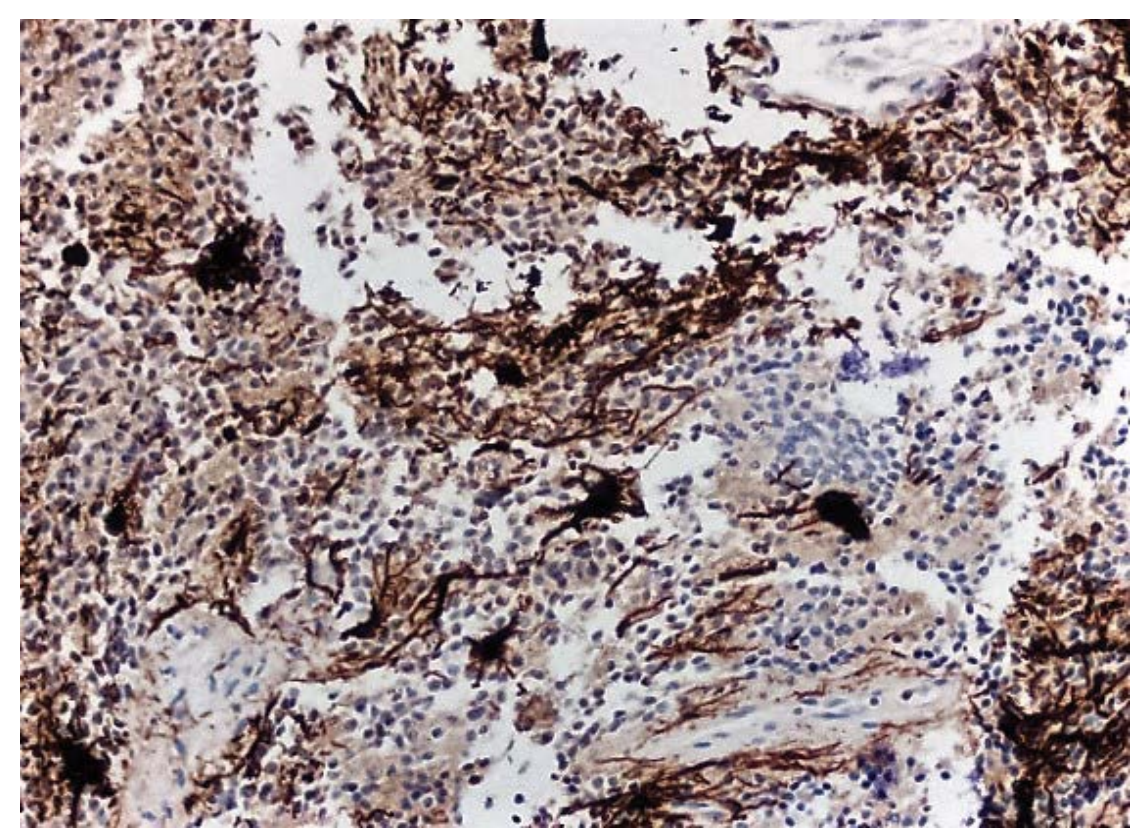

Figure 5: Scattered, multi focal positive reactions with GFAP antibody revealing astrocytic cells with prominent cytoplasmic elongations, (GFAP antibody, DAB chromogen x200). 


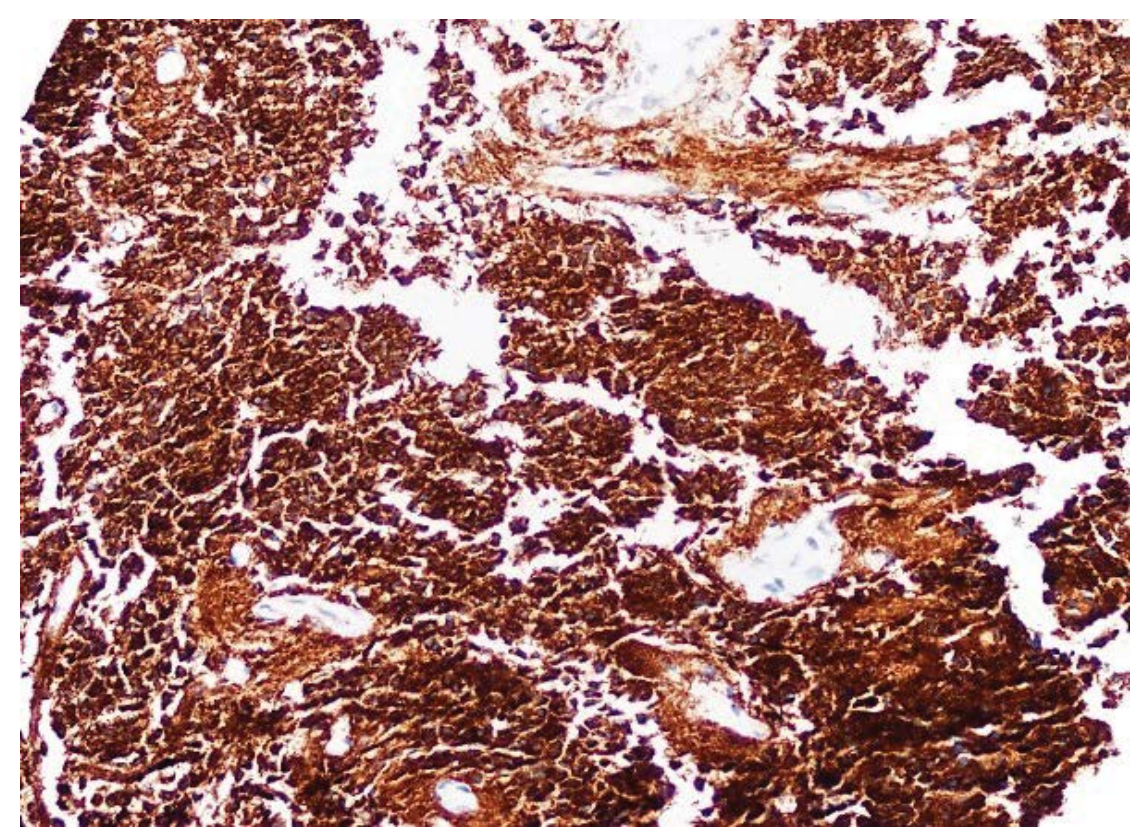

Figure 6: Diffuse strong reaction with synaptophysin antibody revealing cytoplasmic positivity in almost all neoplastic cells (synaptophysin antibody, DAB chromogen x200).

\section{References}

1. Figarella Branger D, Soylemezoglu F, Burger PC, Park $\mathrm{SH}$, Honavar M (2016) Central neurocytoma, in WHO Classification of tumours of the central nervous system. $\left(4^{\text {th }}\right.$ edn), IARC, Lyon, France, 156-158.

2. De Tommasi A, D Urso PI, De Tommasi C, Sanguedolce F, Cimmino A, et al. (2006) Central neurocytoma: two case reports and review of the literature. Neurosurgical Review 29: 339-347.
3. Ahmad Z, Ud Din N, Memon A, Tariq MU, Idrees R, et al. (2016) Central, Extraventricular and Atypical Neurocytomas: a Clinicopathologic Study of 35 Cases from Pakistan Plus a Detailed Review of the Published Literature. Asian Pac J Cancer Prev 17: 1565-1570.

4. Hassoun J, Gambarelli D, Grisoli F, Pellet W, Salamon G, et al. (1982) Central Neurocytoma. An electron-microscopic study of two cases. Acta Neuropathol 56: 151-156. 